\title{
Do Early Intelligent Scores Predict Long-term Achievement: A Quadrennial Longitudinal Study
}

\author{
Tatlı E.C., Ergin D.A.,"* \\ ${ }^{1}$ Department of Psychological Counselling and Guidance, Faculty of Education, Hasan Kalyoncu University, Turkey \\ ${ }^{2}$ Expert Educational Psychologist, Ankara Provincial Directorate of National Education, Turkey
}

Copyright $\bigcirc 2017$ by authors, all rights reserved. Authors agree that this article remains permanently open access under the terms of the Creative Commons Attribution License 4.0 International License

\begin{abstract}
The Purpose of the Study: In this study, establishing a linear regression model that explain academic achievement in terms of assessing academic achievement and intelligence is aimed. Method: In this study, a longitudinal pattern is designed by using 85 students' scores of Culture Fair Intelligence Test (CFIT) (evaluated in 5th grade), Primary Mental Abilities Ages (PMAA) (evaluated in 7th grade) and Transition From Basic To Secondary Education (TEOG) (evaluated in 8th grade). Findings and Conclusion: Findings show that there is positively meaningful relation between PMAA and TEOG scores. In established regression model, the scores of PMAA is seemed to explain the $14 \%$ of the variance. This finding is thought to prove that TEOG is based on the skill of reading comprehension rather than reasoning. For further studies, it is suggested to consider the predictors of personal variables in addition to academic achievement and intelligence scores.
\end{abstract}

Keywords Intelligent, Academic Achievement, Longitudinal Study, Transition from Basic to Secondary Education

\section{Introduction}

Academic achievement is assessed by different ways based on various approaches in the world. For example in Turkey, there are multiple choice assessment systems in exams that are done at national level for different purposes such as determining the students' schools in educational level, civil servant admittance or assessing the level of foreign language proficiency. Transition From Basic to Secondary Education (TEOG) which forms the basic score of determining high school type for 8th graders is one of these exams. This is a multiple choice exam done twice a year while students study at 8th grade and it contains the 8th grade curriculum of Turkish, Maths, Science, Religious Education, Revolution History \& Kemalizm and English [1].
There are similar studies in the world in which Kaufman Test of Educational Achievement (K-TEA) is used to assess the academic success. Dünyada da akademik başarının değerlendirmesinde bu sisteme benzer Kaufman Test of Educational Achievement (K-TEA)'nin kullanıldı̆̆ çalışmalar bulunmaktadır [2]. The results of national standardized examination taken at age 14 are used to make decisions regarding further education and future vocational career. After the exam, following the choice of schools made by students, they are placed to one of the schools they have chosen considering the degree order of their exam results. The students who didn't make choices or couldn't be placed to the schools they chose are placed to open education high schools. Sinav sonrası öğrencilerin okul tercihlerini yapmalarının ardından yerleştirmeye esas puan üstünlüğü baz alınarak öğrenciler tercih ettikleri okullardan birine; tercih yapmayan ya da tercih ettiği okullardan birine yerleşşemeyen öğrenciler ise açık ortaöğretim okullarına yerleştirilmektedir[1]. While students who get high scores from the exam have a right to study in Anatolian High Schools or Science High School, the low scored students are generally directed to Vocational Schools and therefore they experience an earlier and mandatory process of decision in terms of their future work possibilities. Concurrently, differences among students also exist in PISA exam results. According to the Ministry of National Education PISA reports $[3,4]$ the difference in score averages between students who study in Anatolian / Science High Schools and Vocational High Schools is significantly high. Besides, the discrepancy of scores according to school types is high and is over OECD average in Turkey.

According to the vocational guidance, the decision making stage is between 15 and 18 which is high school period. In this period, an individual realizes most of her / his own characteristics. Accordingly, she/he relates herself/himself with the professions. The individual who forms some goals for future aims at the profession and takes a step regarding the profession [5]. If she/he is aimed to Vocational High Schools, she/he has to make professional decision before this period. 
In general terms, despite the concept of "achievement" is defined in different forms, the concept of "academic achievement" is defined as "the ability to perform and achieve in academic domains, such as reading and mathematics" [7]. The body of Literature indicates the relations between academic achievement and different variations such as parenting dimensions and styles $[8,9]$; socioeconomic status [10]; personality factors $[11,12,13]$; attention difficulties and social competence [14]; perfectionism [15, 16, 17]; creativity [18]; cognitive characteristics [19]; intelligent and cognitive ability [20, 21, $22,23]$.

Intelligence which is considered to be related to academic achievement could be evaluated one of the hardest concept to define and assess in body of literature. According to Sternberg [24], definitions of intelligence vary depending on the perspective of the person who defines it. Therefore, there are many different theories about the intelligence types such as, Spearman's g factor theory, Thurstone's multiple factor theory, Guilford's Structure of the Intellect theory, Gardner's Theory of Multiple Intelligences. In Spearman's [25] single factor theory regarding intelligence, general factor or "g", plus one or more specificators can explain people's performances on intelligence tests. People who perform well on a cognitive test tend to perform well on other tests because of the dominant $\mathrm{g}$ factor. On the other hand, in Thurstone's seven factor multiple theory, seven primary mental abilities; verbal reasoning, reasoning, perceptual speed, numerical ability, word fluency, associate memory, and spatial visualization were proposed. Although Thurstone challenged Spearman's theory of $g$, he later cautiously accepted the existence of a general factor [26].

While Spearman accepted some other specific factors in addition to $\mathrm{g}$ factor in his theory's final form, Thurnstone also accepted the existence of a general factor. Therefore, the theories infact seem to be close to each other in their final forms. Above both of these theories that offer a multiple point of view regarding intelligence, Cattel and Horn's Fluid-Crystallized theory offers a hierarchical theory of intelligence and is one of the most comprehensive and emprically validated theories of intelligence [27].

Two basic approaches are presented in assessing the intelligence; verbal and nonverbal tests. In spite of pros and cons in terms of carrying out both of the tests, body of literature reveals the relation between verbal tests and academic achievement. [27, 28] In this study, in an attemp to set up an equation that predicts academic achievement, both verbal and nonverbal assessment tools regarding intelligence were utilised.

\section{Materials and Methods}

\subsection{Participants}

This was a longitudinal study that analyzed study variables across three time points. First assessment scores, Culture Fair Intelligence Test (CFIT), were obtained while the students were in fifth grade. Second assessment scores, Primary Mental Abilities Ages (PMAA), were obtained while they were in the seventh grade and the last one, TEOG, was obtained while they were in the eighth grade. Participants are students of a private school in Ankara/Turkey.In the first assessment, there is a sum of 176 students $\left(\mathrm{n}_{\text {girls }}=85 \mathrm{n}_{\text {boys }}=91\right)$; and in the second assessment the sum is 175 students ( $\left.\mathrm{n}_{\text {girls }}=86 \mathrm{n}_{\text {boys }}=89\right)$. In the last one, 151 students $\left(n_{\text {girls }}=73, n_{\text {boys }}=78\right)$ were contacted. The data of 93 of students whose all results can be matched $\left(\mathrm{n}_{\text {girls }}=44\right.$, $\mathrm{n}_{\text {boys }}=49$ ) is included to the analysis. In normality examination done so as to establish regression model, 8 of the data were determined to be extreme value and were removed from the data set and analysis continued by total of 85 students' scores ( $\left.n_{\text {girls }}=41, n_{\text {boys }}=44\right)$.

\subsection{Instruments}

\subsubsection{Culture Fair Intelligence Test}

The test which was built by Cattell and Cattell [30] was adopted to Turkish byToğrol [31]. The instrument includes two parallel forms (A and B). The paper-and-pencil test assesses fluid intelligence with four types of figural tasks (series, classifications, matrices, and topologies). 2A form was used for the current study.

\subsubsection{Primary Mental Abilities Ages (6-8)}

The original of the test was taken from the Thurston's PMAA (11-17) age group and the study of adapting it to Turkish was done by Şeyhun et al [32]. The test is an assessment tool that results according to the students' language, reasoning and general ability. In PMAA 6-8, raw score is got by evaluating every true answer as 1 point while every false answer as 0 for each item. The test is evaluated by using a norm schedule that is appropriate to student's class and gender and school's residential area. In the original test, there are also results for intelligence part as well as the level of ability. While adjusting the test to Turkey, it was improved to reveal just the abilities but not "intelligence part".

\subsubsection{Transition From Basic To Secondary Education Exam}

Transition From Basic To Secondary Education Exam (TEOG) has been carried out since 2013-2014 educational year. It is a multiple choice exam done twice a year while students study at 8th grade and it contains the 8th grade curriculum of Turkish, Maths, Science, Religious Education, Revolution History \& Kemalizm and English. There are 20 questions for each subject and students have 40 minutes to answer the questions.

\subsection{Procedures}

The data was gathered from a private school students in Ankara. Before the first wave data was gotten in 2015, the 
participants were informed about the research and voluntariness basis was reminded. The CFIT assessments of 176 volunteer students were got by researchers through one on one interview. Second wave data was gathered in 2016. The students who participated to the first wave were applied PMAA by group application and results were assessed by the researchers. Third wave data was got by TEOG scores applied country- wide in 2017.

\subsection{Analysis}

The instruments were administered once a year over three consecutive years. In this process, data loss is usually caused by the school change of the student. On the other hand, although the data were collected from the students who started to the school in the intermediate level, their scores weren't included in the study. For this reason, the total number of analyzed students included in the study was determined as 93. The data of eight students with extreme values that were determined in normality examination were excluded from the study.

In this study, it is aimed to set up a regression model that is produced by CFIT, PMAA and TEOG scores. To determine the predictors of the TEOG score of the study group, it was decided to run multiple linear regression analysis with enter method. The CFIT total score and PMAA total score were included in regression analysis as independent variables. The TEOG score was dependent variable of the regression analysis.

\subsection{Limitations}

Within the research, students in a private school were reached and students in public schools were excluded from the study. CFIT and PMAA tests were used in assessing the students' intelligence scores. Therefore, intelligence concept within the study was limited to the features that the regarding tests measured. In academic success assessment, TEOG scores made country wide in Turkey were examined as the determiner.

\section{Results}

Before the analysis of the regression to be performed within the scope of the purpose of the study before regression analysis, two groups of descriptive analysis were performed:

- Both independent and dependent variables were examined for the whole group as to whether they were normally distributed by using histogram, skewness and kurtosis values. Outliers were removed from the data set and normal distribution was provided in all variables.

- To investigate the relationships between predictor variables and dependent variable, the Pearson correlation values were calculated. Accordingly, since there is no relation between CFIT total score and TEOG scores, CFIT total scores were agreed to be removed from the regression equation. Table 1 includes all means and standard deviation values and the correlation values between dependent and independent variables.

- Multicollinearities in the data were examined by calculating Variance Inflation Factor (VIF), tolerance value (TV) and condition index (CI) values. Calculations indicated that there were no multicollinearity problems for the predictor and dependent variable $(\mathrm{VIF} \leq 10, \mathrm{TV}>.20, \mathrm{CI} \leq 30)$ [33].

According the results of the enter regression analysis run PMAA total score explained $14 \%$ variance in the TEOG score $\left(\mathrm{R}^{2}=139, \mathrm{~F}_{(1,83)}=13.41, \mathrm{p}<0.001\right)$. The results of the regression analysis were summarized in Table 2.

Table 1. Means and standard deviations and correlation values between dependent and independent variables

\begin{tabular}{|c|c|c|c|c|c|}
\hline \multicolumn{2}{|c|}{} & \multicolumn{3}{c|}{ Correlations } \\
\hline Variables & $\mathrm{M}$ & SD & TEOG & CFIT & PMAA \\
\hline 1. TEOG & 94.63 & 2.88 & 1.000 & & \\
\hline 2. CFIT & 135.83 & 17.11 & .188 & 1.000 & \\
\hline 3. PMAA & 89.38 & 7.13 & $.373 * *$ & $.268^{*}$ & 1.000 \\
\hline
\end{tabular}

$*_{\mathrm{p}}<.000 ; * \mathrm{p}<.05$

Table 2. Regression Analysis Predicting the TEOG Score

\begin{tabular}{|c|c|c|c|c|c|}
\hline Dependent variable & Predictor & B & SE & $\beta$ & T \\
\hline TEOG score & PMAA total score & .151 & .041 & .373 & $3.663^{* *}$ \\
\hline \multicolumn{7}{|c|}{$\mathrm{R}: .373$} & $\mathrm{R}^{2}: .139 \quad$ F: 13.415 & $\mathrm{p}=.000$ \\
\hline
\end{tabular}

${ }^{*} \mathrm{p}<.000 ; * * \mathrm{p}<.05$ 


\section{Discussion and Conclusions}

In this study, it is aimed to set up a regression model based on intelligence assessment that predicts academic achievement. For this purpose, both of the verbal and nonverbal materials applied in intelligence assessments were used. Our findings indicated that there was a direct longitudinal link from verbal intelligent score to academic achievement. However, a longitudinal relation between nonverbal assessment and academic achievement wasn't found.

Though different techniques and tools were used while discussing both intelligence measurement and academic success in body of literature, , academic success became one of the most used variables in determining the predictive power of intelligence [34]. Moreover, the prediction of academic success or failure has been the main objective of developing intelligence tests [35]. Many researchers agree that both cognitive and personality variables should be taken into account when predicting school performance $[36,37$, 38].

Studies show that there is a positively strong relation between intelligence and academic success [39]. The power of existing relation changes between 4 and .7 (medium and high) $[40,41,42,43]$. In a study in which CFIT scores were used in Turkey, the relation between intelligence parts and academic success of sixth, seventh and eighth grade students were examined. Accordingly, the predictive power of academic success of intelligence part is .49 [44]. Furthermore, in another study [45] a medium level relation was found between the intelligence scores and academic success of six and seven grade students. The difference of current study than this study is that fifth grade students are included to the sample and longitudinal data is gathered. In another study in which fifth grade students are gathered sampling, there is a significant relation is found between academic success scores and intelligence parts [46]. However, longitudinal data wasn't gathered in this study. Current study provides data that there is no relation between the intelligence parts of kids in preadolescence and their academic success in the eighth grade. This contradictory result shows that it is necessary to make more longitudinal studies that examine relation between the cognitive, emotional and social procedures in preadolescence period and the academic success in middle and/or advanced adolescence period.

In many of the studies in which the relation of academic achievement and intelligence were evaluated, the relation of academic achievement and verbal tests [28, 29] and nonverbal tests [46, 47] were indicated. However, verbal intelligence scores tend to have greater predictive validities of achievement than do nonverbal scores [48]. In the studies that are held, the predictive validities for tests of verbal and quantitative reasoning typically range from $r=.6$ to $r=.8$, whereas unidimensional nonverbal tests have predictive validities that vary from approximately $\mathrm{r}=.3$ to $\mathrm{r}=.6[49$,
50]. As a verbal test, PMAA predicting the TEOG scores whereas not predicting the scores of CFIT which is a nonverbal test, supports the findings of previous body of literature.

In this study, there is no relation found between students' nonverbal intelligence scores assessed in the 5th grade and their academic achievement. While the factors mentioned above could be one the reasons for that, personal variables related to academic achievement is thought to affect the academic achievement of students during that four year. It is important to note that students who are in the 5th grade (age 11) are in the pre-adolescence period and that cognitive differences may have arisen due to the rapid development of adolescents until the 8th term (13-14 years) [51], and therefore it is thought that it could not have predicted the success of the 8 th class. The 6 th grade (12 years old) is in adolescence period and it predicts the academic achievement in the 8 th grade in the adolescence period. Therefore, for further studies, it is suggested to consider the predictors of personal variables in addition to academic achievement and intelligence scores. At the same time, attained findings are thought to prove that TEOG is based on reading comprehension and verbal skills assessment rather than reasoning.

\section{REFERENCES}

[1] MEB (2017) Retrieved from http://www.meb.gov.tr/meb_iys_dosyalar/2017 06/0717102 72017 YILI_TERCYH_VE_YERLEYTYRME_e-KILAV UZUUU.p.pdf

[2] Bellinger, D. C., Stiles, K. M., \& Needleman, H. L. (1992). Low-level lead exposure, intelligence and academic achievement: a long-term follow-up study. Pediatrics, 90(6), 855-861.

[3] MEB (2016) PISA 2015 Ulusal Raporu. Retrieved from http://pisa.meb.gov.tr/wp-content/uploads/2016/12/PISA201 5_Ulusal_Rapor1.pdf.

[4] MEB (2014). 2016-2017 eğitim öğretim yılı ortak sınavlar ek1lavuzu. Retrieved from

http://www.meb.gov.tr/meb_iys_dosyalar/2016_10/0706215 0_20162017retimylortaksnavlareklavuzu.pdf.

[5] Kuzgun, Y. (2014). Meslek Gelişimi ve Danışmanlığı (4th edition). Ankara: Nobel Publishing.

[6] MEB (2015). PISA 2012 Araştırmast Ulusal Nihai Rapor. Retrieved from http://pisa.meb.gov.tr/?page_id=22.

[7] Mayers, R. E. (2011). Intelligence and achievement. In R. J. Sternberg \& S. B. Kaufman (Eds.), The Cambridge handbook of intelligence (pp. 738-747). New York, NY: Cambridge University Press.

[8] Masud, H., Thurasamy, R., Ahmad, M.S. (2015). Parenting styles and academic achievement of young adolescents: a systematic literature review. Quality and Quantity. 
[9] Turner, E. A., Chandler, M., \& Heffer, R. W. (2009). The influence of parenting styles, achievement motivation, and self-efficacy on academic performance of college students. Journal of College Student Development, 50, 337-346.

[10] Korpershoek, H., Harms, T., de Boer, H., van Kuijk, M., \& Doolaard, S. (2016). A meta-analysis of the effects of classroom management strategies and classroom management programs on students' academic, behavioral, emotional, and motivational outcomes. Review of Educational Research, 86(3), 643-680.

[11] Hofer, M., Kuhnle, C., Kilian, B., \& Fries, S. (2012). Cognitive ability and personality variables as predictors of school grades and test scores in adolescents. Learning and Instruction, 22(5), 368-375.

[12] Poropat, A. E. (2009). A meta-analysis of the five-factor model of personality and academic performance. Psychological bulletin, 135(2), 322.

[13] Spengler, M., Brunner, M., Martin, R., \& Lüdtke, O. (2016). The role of personality in predicting (change in) students' academic success across four years of secondary school. European Journal of Psychological Assessment, 32(1), 95.

[14] Rabiner, D. L., Godwin, J., \& Dodge, K. A. (2016). Predicting academic achievement and attainment: the contribution of early academic skills, attention difficulties, and social competence. School Psychology Review, 45(2), 250-267.

[15] Bong, M., Hwang, A., Noh, A., \& Kim, S. (2014). Perfectionism and motivation of adolescents in academic contexts. Journal of Educational Psychology, 106, 711-729.

[16] Damian, L. E., Stoeber, J., Negru-Subtirica, O., \& Băban, A. (2016). On the development of perfectionism: The longitudinal role of academic achievement and academic efficacy. Journal of personality.

[17] Stoeber, J. (2012). Perfectionism and performance. In S. M. Murphy (Ed.), The Oxford handbook of sport and performance psychology (pp. 294-306). New York: Oxford University Press

[18] Mourgues, C., Tan, M., Hein, S., Elliott, J. G., \& Grigorenko, E. L. (2016). Using creativity to predict future academic performance: An application of Aurora's five subtests for creativity. Learning and Individual Differences, 51, 378-386.

[19] Morosanova, V. I., Fomina, T. G., Kovas, Y., \& Bogdanova, O. Y. (2016). Cognitive and regulatory characteristics and mathematical performance in high school students. Personality and Individual Differences, 90, 177-186.

[20] Diamond, E., Furlong, M. J., \& Quirk, M. (2016). Academically Resilient Latino Elementary Students Bridging the Achievement Gap. Contemporary School Psychology, 20(2), 160-169.

[21] Mandelman, S. D., Barbot, B., \& Grigorenko, E. L. (2016). Predicting academic performance and trajectories from a measure of successful intelligence. Learning and Individual Differences, 51, 387-393.

[22] Pearce, A., Sawyer, A. C., Chittleborough, C. R., Mittinty, M. N., Law, C., \& Lynch, J. W. (2016). Do early life cognitive ability and self-regulation skills explain socio-economic inequalities in academic achievement? An effect decomposition analysis in UK and Australian cohorts. Social
Science \& Medicine, 165, 108-118.

[23] Van Rooij, E. C., Jansen, E. P., \& van de Grift, W. J. (2017). Secondary school students' engagement profiles and their relationship with academic adjustment and achievement in university. Learning and Individual Differences, 54, 9-19.

[24] Sternberg, R. J. (2003). Wisdom, intelligence, and creativity synthesized. New York, NY: Cambridge University Press. doi:10.1017/CBO9780511509612

[25] Spearman, C. (1904). "General intelligence," objectively determined and measured. American Journal of Psychology 15, 201-293. doi:10.2307/1412107

[26] Wasserman, J. D., \& Tulsky, D. S. (2005). A history of intelligence assessment. Contemporary intellectual assessment: Theories, tests, and issues, 3-22.

[27] Flanagan, D. P., \& McGrew, K. S. (1997). A cross-battery approach to assessing and interpreting cognitive abilities: Narrowing the gap between practice and cognitive science.

[28] Juntune, J., Kaya, F., \& Ramos, S. (2011). Another look at high ability students from low SES populations. Tempo, 32(4), 14-19.

[29] Lee, S. Y., Olszewski-Kubilius, P., \& Peternel, G. (2010). The efficacy of academic acceleration for gifted minority students. Gifted Child Quarterly, 54(3), 189-208.

[30] Cattell, R. B., \& Cattell, A. K. S. (1960). Handbook for the individual or group culture fair intelligence test. Savoy, IL: Institute for Personality and Ability Testing.

[31] Toğrol, B. (1974). Rb Cattell zeka testinin 2a ve 2b formlar1 ile porteus labirenti zeka testinin 1300 Türk çocuğuna uygulanması. Psikoloji Çalışmaları Dergisi, 11, 1-32.

[32] Şeyhun, H., Gökçe, S., \& Şen, H. (2003). Temel Yetenekler Testi 6-8 TYT (6-8) el kitabı (ss.1-58). Ankara: Milli Eğitim Basımevi.

[33] Field, A. (2009). Discovering statistics Using SPSS. London: Sage Publication.

[34] Deary, I. J., Strand, S., Smith, P., \& Fernandes, C. (2007). Intelligence and educational achievement. Intelligence, 35(1), 13-21.

[35] Ackerman, P. L., \& Heggestad, E. D. (1997). Intelligence, personality and interests: Evidence for overlapping traits. Psychological Bulletin, 121, 219-245.

[36] Chamorro-Premuzic, T., \& Furnham, A. (2005). Personality and intellectual competence. New Jersey: Lawrence Erlbaum Associates.

[37] Rindermann, H., \& Neubauer, A. C. (2001). The influence of personality on three aspects of cognitive performance: processing speed, intelligence and school performance. Personality and Individual Differences, 30, 829-842.

[38] Rothstein, M. G., Paunonen, S. V., Rush, J. C., \& King, G. A. (1994). Personality and cognitive ability predictors of performance in graduate business school. Journal of Educational Psychology, 86, 516-530.

[39] Jensen, A. R. (1998). The g factor: The science of mental ability. Westport, CT: Praeger.

[40] Fischer, C. S., Hout, M., Jankowski, M. S., Lucas, S. R., Swidler, A., \& Voss, K. (1996). Inequality by design: 
Cracking the bell curve myth. Princeton, NJ: Princeton University Press.

[41] Jencks, C., Bartlett, S., Corcoran, M., Crouse, J., Eaglesfield, D., Jackson, G., ... Williams, J. (1979). Who gets ahead? The determinants of economic success in America. New York, NY: Basic Books.

[42] Mackintosh, N. J. (1998). IQ and human intelligence. Oxford: Oxford University Press.

[43] Duckworth, A. L., \& Seligman, M. E. (2005). Self-discipline outdoes IQ in predicting academic performance of adolescents. Psychological science, 16(12), 939-944.

[44] Dağl1, M.A. (2006). Ergenlikte zeka bölümü, duygusal zeka ve akademik başari arasindaki ilişki. Unpublished master's thesis. Mersin University, Mersin Turkey.

[45] Kaya, F., \& Oğurlu, Ü. (2015). The relationship among self-esteem, intelligence, and academic achievement Benlik saygıs1, zekâ ve akademik başarı ilişkisi. Journal of Human Sciences, 12(1), 951-965.

[46] Korkmaz, U. (2014). Predicting academic achievement: The role of parenting, nonverbal intelligence, and goal orientation in Turkish children (Doctoral dissertation, Texas A\&M University).

[47] Naglieri, J. A., \& Ronning, M. E. (2000). Comparison of White, African American, Hispanic, and Asian children on the Naglieri Nonverbal Ability Test. Psychological Assessment, 12(3), 328.

[48] Lakin, J. M., \& Lohman, D. F. (2011). The predictive accuracy of verbal, quantitative, and nonverbal reasoning tests: Consequences for talent identification and program diversity. Journal for the Education of the Gifted, 34(4), 595-623.

[49] Powers, S., \& Barkan, J. H. (1986). Concurrent Validity of the standard progressive matrices for Hispanic and nonHispanic and seventh-grade students. Psychology in the Schools, 23(4), 333-336.

[50] McCallum, R. S., Bracken, B. A., \& Wasserman, J. D. (2001). Essentials of nonverbal assessment. John Wiley \& Sons Inc.

[51] Santrock, J.W. (2009). Life-Span Development 14th Ed. Boston: McGraw-Hill. 